\title{
Impact of Human Resource Strategies of the United States on China
}

\author{
Yun $\mathrm{Li}^{1}$ \\ ${ }^{1}$ Guangdong University of Foreign Studies, Guangzhou, China \\ Correspondence: Yun Li, postgraduate student, Guangdong University of Foreign Studies, Guangzhou, China.
}

Received: August 6, 2017

Accepted: August 17, 2017

Online Published: August 21, 2017

doi:10.5430/jms.v8n4p62

URL: https://doi.org/10.5430/jms.v8n4p62

\begin{abstract}
A developed and mighty America has attracted world attention. At the same time, it Provokes our deep thought on the reason for its rapid development within 300 years into the world's leading superpower, Outdistancing all other countries in politics, economy, military strength, and culture.

After researching and Pondering, I conclude that American development in a large degree lies in its effective human resource strategies. Peace and development have become the two main topics in the Present world. We can borrow some experience from American development and gain some suggestions for the benefit of our own development into power. There are other hills whose stones are good for working jade.
\end{abstract}

Keywords: human resource, strategy, attract, cultivate

\section{Introduction}

The strong economic Power of the United Stats provides a strong basis for its military strength. "Its defense budget... accounts for about 35 percent of the world's total annual military expenditures... The United States not only leads the pack but outdistances its closest rival by more than a factor of three.

The result of America's profligate defense spending is that the United States has by far the largest and most capable of the world's air forces and navies; an army that can defeat any other; and a marine corps that has Personnel and equipment comparable to the entire armed forces of the United Kingdom."

The United States holds a commanding lead in the number of nuclear weapons. Moreover, the United States often took the lead in the North Atlantic Treaty Organization to oppose the weapon Treaty Organization. Although the Soviet Union disintegrated and the Warsaw Pact was disbanded in the 1990s, NATO does not dissolve, on the contrary, it has enlarged even to the Eastern Europe in recent years. Nowadays, the United States is "the only country with both intercontinental nuclear weapons and large, modern, air, naval, and ground forces capable of deploying around the world". Combined with its development of information industry and aero space technology, the military power of the United States sees no rival in the whole world.

Why can the United States develop into the world'5 leading superpower within less than 300 years? Are there some secrets of success? Can they be used in China? Since its man who works all miracles under the heaven, the American development can not be understood without a full analysis of its human resource strategies. History shows that the strategies of the United States to attract, cultivate human resources are the most important and decisive factor of its development. This thesis concentrates on the analysis of the definition and significance of U.S. human resources, the U.S. human resource strategies and their suggestions for China to attract, cultivate human resources.

\section{The Significance of Human Resource to the Development of the United States}

\subsection{Definition and Strategies of Human Resources}

William R. Tracey defines human resources in the Human Resources Glossary as "the people that staff and operate an organization...as contrasted with the financial and material resources of an organization. The Organizational function that deals with the people..."

Fredrick H. Harrison defines human resources as "the energies, skills, and knowledge of People which are, or which potentially can or should be, applied to the Production of goods or the rendering of services. Thus, the term connotes man in relationship to the world of work, and such work involves poducing things and Providing services of all kinds in the social, political, cultural, and economic development of nations". From these definitions, we can sense that 
human resources are the Population with labor force to drive the development of economy and society.

Therefore, human resources are considered by many economists as a kind of capital.

Compared with other kinds of resources, human resource has four distinctive characteristics:

First, human resource is an active and motile resource. It is the Principal and essential difference of human resource from all other resources. Human resource takes a dominant role in the economic activities. It is the activities of human kind which trigger, control, and drive the activities of other resources. Moreover, only human resource is a creative factor in the economic activities. The lifeblood of the economic activities is development, aggressiveness, and innovation, and only human resource can assume these tasks.

Second, human resource is a special kind of capital. Human resource has the characteristics of other kinds of capital in common. But the rate of returns of human resource follows the law of progressive increase compared with other kind of capital. Therefore, the increase in the contemporary economy should be chiefly attributed to human resource.

Third, human resource is a kind of resource with high-added value. The share of the returns from human resource is rapidly exceeding other resources, such as material resource and financial resource. The increasing effect of human resource results from its Process of self-compensation, renewal, and development in use.

TO sum up, human resource is the most active factor in the Productive forces. The competition of the national strength in the final analysis is the competition of talent resource in the present world.

\subsection{Contribution of Human Resources to the Development of the U.S}

\subsubsection{Contribution to the Funding of the U.S.}

The history of the colonial America began in an age of geographic discovery the late $15^{\text {th }}$ century Europe, the demand for spices, textiles and dyes from Asia urged the Europeans to find an easier and cheaper Passageway to Asia out of the need for the increased trade. An error in navigation led the Europeans to encounter and exPlore America.

The first successful English colony in America was founded at Jamestown, Virginia, in 1607. The settlement was financed by a London company to search for wealth, therefore the colonists had no intention of settling there and spent much effort in securing food from the Indians and searching for gold. Of the first 105 colonists, 73 died of hunger and diseases. And the Indians became more resistant. In 1609, the Virginia Company made a determined effort to save the colony. A governor who would reside in the colony was appointed and more effort was made to diversify the economy and spread out settlement. The idea of outP0st was abandoned and the colony began to emphasize agriculture. Enduring innumerable trials and hardships, the colonists survived and Prospered by growing tobacco.

Gradually, English settlers had occupied 13 colonies along the Atlantic coast, from New Hampshire in the north to Georgia in the south by 1733 . Within one and a half centuries, the economy of the colonial America developed rapidly. Due to the varying geographic and climatic conditions and different range of natural resources, the colonies developed a diversified economy. There were mainly three distinctive regional economies.

Under the influence of the New World environment, the colonists became self-reliant, adaptable, enterprising and tolerant. In an open wideness, they had to accommodate themselves to the geographic and climatic conditions, developing suitable economies to survive and Prosper. Meanwhile, the vast land gave them the chance to start easily a new life at any Place. Therefore, if someone could not be accepted in one colony out of political or religious reason, they could move to another. Under such circumstances, the United States was shaped into an open system with Pluralism and toleration. The New world environment and economic development shaped the character of both the colonists and the new nation.

The immigrants contributed significantly to the founding of the United States. The growth and expansion of the colonies, the economic development, the establishment of the Political Patterns, and the distinctive social and cultural characteristics were all traceable to the course of colonization and the founding of the United States.

\subsubsection{Contribution to the "American Century"}

In the rise of American industry, the techniea1 skills of human resources were a key factor. The new technology which was carried by the immigrants to the United States was the basis of industrialization. The initial Phase of American industrial development depended heavily on the skilled labor of the European immigrants, such as artisans, operatives, superintendents, and entrepreneurs. Meanwhile, human resources of the United States supplied industry with the labor it needed for development. With the efforts of the human resources, American industry developed rapidly and adapted itself to the new conditions. Machinery was improved and new production methods were 
developed. As the United States was transformed into industrial economy, Americans turned their attention from internal affairs to active participation in overseas expansion and international affairs. The growing industrialization made it Possible and Promising for the United States to become the leading Power of the world. Human resources, especially the talent resources, were the key factor for the United States to climb up to the world's leading Position.

After World War Two, the United States was by far the strongest Power. The new world order was Primarily created by the United States. The Post-war Political Pattern was designed for the division of sphere of influence, relying on its economic Power, the United States established the international monetary system centering on the U.S. dollar and the imitational trade system according to American principle. At Present, no other country can match the United States Politically, economically, militarily, and culturally. The $20^{\text {th }}$ century was the "American century" as Henry Luce envisioned. To a great extent, the supremacy of the United States was the result of its human resource strategies to attract and exploit the talents with advanced science and technology.

\section{The Human Resource Strategies of the U.S}

Before the seventeenth century, America was explored slightly by European powers in search of wealth. Until the early seventeenth century, the successful establishment of the English colonies in America inspired the successive mass immigration and began the American national history. Although the United States is more inclined to receive immigrants than any other country, it never takes an open-door Policy without discrimination toward immigration. The United States has adopted the human resources strategies to attract, and cultivate the needed ones.

\subsection{The U.S Strategies to Attract the Needed Human Resources}

In the land the immigrants had left, vast estates abounded and opportunities for ordinary People were few. In the American land to which they came, the limitless wildness was the greatest lure to them. The colonies had an excess of land and a shortage of People, so it was the Public Policy to encourage Population growth through Promises of cheap land. In addition, the colonies carried out other Practices to attract immigrants. In the early years, when men greatly outnumbered women, some colonies offered special land grants to husbands migrating with wives. Occasionally, land was granted directly to individuals for special reasons, such as a reward for service or Promotion of industrial development.

At the colonial Period, an attitude of Prevailing welcome to ward free immigration was taken. To the motherland, the American colonies were regarded as a dumping ground for undesirables. To the colonies, immigrants represented the solution of labor shortage, the means of promoting land settlement and developing resources, the channel to increase revenue, and the safe guard to frontier defense and internal security. But even the colonies needed immigrants, the authorities did not adopt a completely open-door policy. Certain classes of immigrants were unwelcome on account of religious affiliation, economic status, and moral standing. The principles to as certain the value of the immigrants lay in their skills and occupations. The first and most useful class was those bringing with moral habits and Physical habits and capacity of productive labor. The next was the artist of solid and substantial articles. Then was the commercial class with property and capital. In order to attract immigrants to fill and exploit the empty continent, the colonies carried out favorable immigration policy to welcome and encourage the needed immigrants to the United States. America welcomed almost everyone who could finance the precarious trip across the Atlantic. Correspondingly, the colonies would grant land to individuals in proportion to the number of settlers whose fares they Paid. And the colonies would make substantial and grants to entrepreneurs who undertook to bring immigrants from Europe to unsettled regions. Some colonies passed laws exempting immigrants for specified Periods from taxation, and others offered bounties to pay the cost of their ocean voyage and Provided new arrivals with free land.

\subsection{The U.S Strategies to Cultivate Human Resources}

Besides attracting and exploiting human resources from other countries, the United States also pays attention to cultivating human resources. The United States attaches great importance to the cultivation of human resources through education. The U.S. tradition of valuing education was set up from theological period. In the $17^{\text {th }}$ and $18^{\text {th }}$ centuries, education was generally used to maintain the authority of government and religion. People were taught to read and write so that they could obey the laws of God and the state. The Puritans thought the function of education was to enable that "the youth in so wild a country where there are so many dissolute People may first of all be well in strutted and indoctrinated, not only in reading and Writing, but also in the knowledge and fear of Lord". In addition, the education of Puritan New England emphasized on individual conduct, therefore, education was also regarded as a panacea for society.

At Present, all American children are obliged to take 12 years of free public education. Colleges and universities offer a vast array of subjects. And most Poor students can enjoy financial aid for the higher education. Students can 
sample different fields of knowledge, but usually concentrate in one field as their majors during the last two years. They can also obtain Professional trainings at the undergraduate level, such as accounting, teaching and journalism. In addition, the United States has borrowed the successful experience of European education and formed its own distinctiveness. The research universities of the United States were established through imitating the European mode by some German doctors. Meanwhile, the United States has never ceased increasing its educational investment. The U.S. investment on education is far more than all the other countries. And the United States Possesses the most advanced hardware and software in education. Therefore, the United States has the most advanced education system in today's world.

And the first-class universities of the United States have surpassed the European universities in reputation and merit. Before World War Two, the rich Americans would send their children to study in Europe, for better education. But the circumstance has greatly changed since World War Two. The excellent students all over the world yearn and strive to study in the first-class universities of the United States.

\section{Some Suggestions to China}

\subsection{Reform of Education and Training System}

What we need is to reform the education and training system in order to meet the needs of economic and social development and bring innovative system into practice. It will take a long time and much effort for us to grope the successful education practice in the advanced countries. We should follow the example of the United States to make full use of foreign brains, bringing in Professionals and scholars who are familiar with and expert in the education practice to perfect our education system. We can attract them with munificent rewards or through communication with and exchange of visiting scholars or guest scholars. In order to suit the human resource structure to the demand of the development of science and technology talent resources of different levels and fields, especially the urgent-needed Professionals, should be cultivated under the regulation of government. In order to improve the education quality, we should strengthen the cooperation and communication with the foreign high schools and institutes and boldly borrow the successful experience of other countries on education. The good curriculum and teaching method should be introduced into our education system. Through the reform of education and training system, we can transform the abundant human resources into talent resources in the long run.

\subsection{Reform of the Personnel System}

Scientific placement mechanism and reasonable reward system is the key to accumulate and retain talent resources. China should set up Policies to eliminate the obstacles affecting the development and exploitation of talent resources. The unreasonable practice, such as giving to priority to seniority in promotion and appointing people by favoritism and nepotism, should be abolished. Indeed, affair and effective appraisal system should be developed. The criteria for the selection of talent resource should be based on knowledge, capability, performance and moral character. Meanwhile, the appraisal of talent resources in different fields should be different. The appraisal of talent resources in the governmental or generations should be based on the substantial results and the acceptance and approval of the masses; the appraisal of management talent resources in enterprises should be based on the economic returns and the recognition of the market and the owners of the enterprises; the appraisal of professionals should be based on the research achievements and the recognition of experts in the specialty. The cultivation of governmental cadres, management Professionals and Professional technicians should be strengthened. In addition, the obstacles hindering the mobility of talent resources should also be eliminated, such as census register, Personal archives, and social security system.

\subsection{Establishment of Perfect Social Security System}

Mobility is encouraged for the reasonable Placement and full exertion of human resources. But the mobility of human resources should be based on perfect social security system. Social security system can maintain social stability, promote economic development, and regulate social equity. The establishment of a perfect socials security system can provide talent resources with the sense of security. Therefore, they can go all out for the development and prosperity of China. The U.S. social security system covers a wide range and is generalized in the whole society. The difference of old-age, unemployment, and medical insurance premiums among different working places is slight. Therefore, the mobility of human resources is easy without incurring loss of social security cost.

\section{Conclusion}

Through analysis on the problems existing in current human resource development and exploitation in China, the author brings forward some useful suggestions: the present conditions of human resources can be changed through reform of education and training system, creation of sound mechanism for exploiting human resources, reform of the 
personnel system, and establishment of perfect social security system. By these means, our human resources can be changed into competitive ones and exerted to the best advantage.

This thesis is a shallow attempt in the development and exploitation of human resources. Due to the limitation of the author's knowledge and capacity, the exploration of the issue is not thorough and profound enough. Still, the present author hopes that the thesis can be useful to further researches. At the same time, the author hopes scholars and experts will offer some advice and criticism without stint for the Perfection of the thesis

\section{References}

Armstrong, Michael, \& Baron, Angela. (2002). Strategies HRM: The Key to Improved Business Performance. London: Chartered Institute of Personal and Development.

Baldick, Chris. (2001). Concise Dictionary of Literary Terms. Shanghai: Shanghai Foreign Language Education Press.

Berlin, Carol, \& Miller, Christopher L. (1995). Making American: A history of the United States. Boston: Houghton Mifflin, 1995.

Cary, John H., \& Weinberg, Julius (Eds.). (1981). The Social Fabric ( $3^{\text {rd }}$ ed.). Boston: Little, Brown and Company.

Harbison, Fredrick H. (1973). Human Resources as the Wealth of Nations. New York: Oxford University Press.

Jones, Maldwyn Allen. (1960). American Immigration. Chicago and London: The University of Chicago Press.

Norton, Mary Beth et al.. (1988). A People and a Nation: A history of the United States (Vol. B, brief edition). Boston: Houghton Mifflin Company.

Tocqueville, Alexis de. (1945). Democracy in America. New York: Vintage Books.

Wittkopf, Eugene R., \& Jones, Christopher M. (Eds.). (2003). The Future of American Foreign Policy. Beijing: Peking University Press.

Woodward, c. Vann (Ed.). (1983). A Comparative Approach to American History. Washington D. C.: Forum Series. 